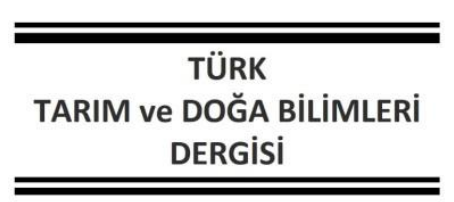

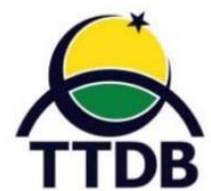

www.dergipark.gov.tr/turkjans

Araştırma Makalesi

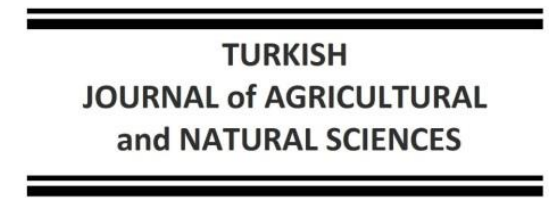

and NATURAL SCIENCES

\title{
Sedir Odununun Bazı Fiziksel ve Mekanik Özelliklerinin Belirlenmesi Üzerine Bir Araştırma
}

\author{
Fatih Tuncay EFE ${ }^{1 *}$
}

\author{
${ }^{1}$ Çanakkale Onsekiz Mart Üniversitesi, Yenice Meslek Yüksekokulu, Ormancılık Bölümü, Çanakkale \\ *Sorumlu Yazar: fatihtuncayefe@gmail.com
}

Geliş Tarihi: 11.10.2020, Düzeltme Geliş Tarihi: 17.11.2020, Kabul Tarihi: 15.01.2021

\section{Öz}

Toros sediri Türkiye'de Akdeniz bölgesinde doğal olarak yetişen bir ağaç türüdür. Toros sedirinin odunu, biyolojik olarak oldukça dayanıklı olması nedeniyle geçmişte birçok kullanım alanı bulmuştur. Toros sediri odununun yoğunluk, genişleme yüzdeleri, lif doygunluk noktası, su alma yüzdesi gibi fiziksel özellikleri ve ayrıca, eğilme direnci, elastikiyet modülü, şok direnci ve vida tutma direnci gibi mekanik özellikleri araştırılmıştır. Elde edilen verilere göre, Toros sediri odununun tam kuru yoğunluğu, hacmen genişleme yüzdesi, lif doygunluk noktası sırasıyla; $497 \mathrm{kgm}^{-3}, \% 10.6$ ve \%21.3 olarak belirlenmiştir. Ayrıca, eğilme direnci, elastikiyet modülü, şok direnci ve vida tutma kapasitesi (radyal, teğet ve enine yönde) sırasıyla; $94.3 \mathrm{Nmm}^{-2}, 8069 \mathrm{Nmm}^{-2}, 0.210 \mathrm{kgmcm}^{-2}$ ve (29.7 $\mathrm{Nmm}^{-2}, 31.4 \mathrm{Nmm}^{-2}$ ve $28.5 \mathrm{Nmm}^{-2}$ ) olarak tespit edilmiştir. Elde edilen bu verilere göre; Toros sediri odununun orta yoğunluk değerine, düşük genişleme yüzdesine ve düşük lif doygunluk noktasına sahip olduğu söylenebilir.

Anahtar kelimeler: Toros sediri, mekanik özellikler, fiziksel özellikler

\section{A Study on the Determination of Some Physical and Mechanical Properties of Wood of Taurus Cedar}

\begin{abstract}
Taurus cedar grows naturally in the Mediterranean region in Turkey. Toros Cedar wood has found many uses in the past due to its biological durability. Physical properties of Taurus cedar wood such as density, swelling percentages, fiber saturation point, water uptake percentage, as well as mechanical properties such as bending strength, modulus of elasticity, impact bending strength and screw holding resistance were investigated. According to the data obtained, the oven-dried density of Taurus cedar wood, the percentage of volumetric swelling, and fiber saturation point were determined as $497 \mathrm{kgm}^{-3}, 10.6 \%$ and $21.3 \%$, respectively. In addition, bending strength, modulus elasticity, impact bending strength and screw holding capacity (radial, tangential and axial direction) were determined as $94.3 \mathrm{Nmm}^{-2}, 8069 \mathrm{Nmm}^{-2}, 0.210 \mathrm{kgmcm}^{-2}$ and $\left(29.7 \mathrm{Nmm}^{-2}, 31.4 \mathrm{Nmm}^{-2}\right.$ and $28.5 \mathrm{Nmm}^{-2}$ ) respectively. It can be said that Taurus cedar wood has medium density value, low expansion percentage and low fiber saturation point.
\end{abstract}

Key words: Cedar wood, mechanical features, physical features

\section{Giriş}

Sedir ağacının odununun genel olarak tanımlanmasıyla ilgili bazı bilgiler bulunmaktadır. Bu bilgilere göre; Sedir ağacının diri odunu geniş, kırmızımtırak ile sarımsı beyaz renkte, öz odunu açık sarı ile kırmızımsı kahverengindedir. Traumatik reçine kanalları sıkça bulunur. Boyuna kesitleri oldukça parlaktır. Odunu orta sert ve orta ağırlıkta olup hoş kokuludur. Kolay işlenir ve yarılır. Lifleri düzgündür. Renk verme ve cilalanması zordur. Yapıştırılma özellikleri iyidir. Az çalışır, mekanik direnç değerleri orta derecededir (Bozkurt ve Erdin, 1997). Çok dayanıklı sınıfında olup; doğal dayanıklılı̆ı 20-25 yıldır (Göker, 1992; Doğu ve ark. 2001). Toros sediri dayanıklı bir oduna sahip oluşu nedeniyle geniş bir kullanım alanı vardır. Toprakla 
temas eden yerlerde, tel direği, çit direği, maden direği, travers olarak ve köprü inşaatında kullanılır. Az budaklı ve dar yıllık halkalı malzeme olduğundan, binalarda içi ve dış maksatlarda, kapı, pencere doğramaları, lambri ve mobilya yapımında kullanılır. Bunlardan başka parke, bahçe mobilyası, merdiven, balkon, kurşun kalem, arı kovanı yapımında, seralarda taşıyıcı materyal olarak, ambalaj kâğıdı yapımında ve kalıplık dikme olarak kullanılır. Kendisine özgü kokusu ve güve uzaklaştırıcı etkisi nedeniyle, elbise sandık ve dolapların yapımında da kullanılır (Öktem ve Sözen, 1992).

Sedir odununun teknolojik özellikleri üzerine yapılan önceki çalışmalarda, fiziksel, mekanik, kimyasal özellikleri ve işlenme özellikleri araştırılmıştır. Örneğin, Toros sedirinin genç odun ve olgun odununun bazı fiziksel ve mekanik özellikleri araştırılmış ve genç odunun hava kurusu yoğunluk, tam kuru yoğunluk, hacmen daralma, hacmen genişleme ve lif doygunluk noktası ve taze hal rutubeti sırasıyla $574 \mathrm{kgm}^{-3}, 524 \mathrm{kgm}^{-3}, \% 8.45$, \%9.27 \%17.92 ve \%37.2 ve aynı sıra ile olgun odunun $588 \mathrm{kgm}^{-3}, 547 \mathrm{kgm}^{-3}, \% 11.86, \% 12.92$, $\% 24.48$ ve $\% 128.2$ olarak ölçülmüştür. Genç odunda eğilme direnci, elastikiyet modülü, $75.8 \mathrm{Nmm}^{-2}$, $6668 \mathrm{Nmm}^{-2}$ ve olgun odunun aynı sıra ile 94.4 $\mathrm{Nmm}^{-2}, 8963 \mathrm{Nmm}^{-2}$ olarak belirlenmiştir (Bal ve ark., 2012). Öktem ve Sözen (1992) sedir odununun anatomik ve teknolojik özellikleri ile kullanım yerleri üzerine yaptıkları çalışmada Toros sedirinde basınç direncine bağlı olarak bulunan statik kalite değerini 8.6; spesifik kalite değerini 16.4 olarak ifade etmişler; bu değerlerin Toros sediri, odununun statik etkilere karşı iyi özelliklerde olduğunu, spesifik kalite değeri bakımından ise Pinus nigra Arnold. subsp. pallasiana ile Pinus sylvestris'ten daha yüksek olduğunu belirtmişlerdir. Sofuoğlu ve Kurtoğlu (2015) tarafından yapılan bir araştırmada Lübnan sediri odununun işlenme ve zımparalanma özelliklerini incelenmiştir. Çalışmada kullanılan odunun yoğunluğu $0.501 \mathrm{gcm}^{-3}$ olup; planya makinesi ile rendeleme ve zımparalama sonunda odunun yüzey pürüzlülüğü ortalama $4.836 \mu \mathrm{m}$ olarak ölçülmüştür. Bu değer karakavak ile karaçam odununun arasındadır. Ayata ve ark. (2018) tarafından, sedir (Cedrus libani A. Richard), doğu çınarı (Platanus orientalis L.), dut (Morus Sp.) ve kızılçam (Pinus brutia Ten.) odunlarının janka sertlik değerleri araştırılmıştır. Sonuçta, tüm ağaç türlerinin enine yüzeylerinde ölçülen değerlerin teğet ve radyal yüzeylerdekinden yüksek olduğu; dut, doğu çınarı ve kızılçam odunlarında teğet yüzeylerinin sertlik değerlerinin radyal yüzeylerininkinden yüksek, sedir odununda ise tam tersi bir durum olduğu tespit edilmiştir. Ferah (1991), bazı önemli ağaç türlerimizin vida ve çivi tutma direnç özelliklerinin belirlenmesi amacıyla yaptığı bir araştırmasında Toros sedirini (Cedrus libani A. Richard) de incelemiştir. \%12 rutubette teğet, radyal ve enine kesitte çivi tutma dirençlerini sırasıyla 109 kgf, 108 kgf ve 78 kgf olarak belirlenmiştir.

Yapılan önceki çalışmaların bir kısmı farklı coğrafyalarda yetişen sedir odunuyla ilgili, önemli bir kısmı sedir odununun uçucu yağları ile ilgilidir. Bu çalışmada ise Türkiye'de ticareti yapılan Toros sedirinin uygulayıcılar açısından önemli olan bazı önemli fiziksel ve mekanik özellikleri araştırılmıştır.

\section{Materyal ve Metot Materyal}

Denemelerde kullanılan Toros sediri (Cedrus libani A. Rich) odunu Adana Orman İşletme Müdürlüğü deposundan temin edilmiştir. Test örnekleri hazırlanmadan önce doğal kurutma işlemi uygulanmıştır. Sonra test örnekleri hazırlanmıştır. Hazırlanan test örnekleri, $20 \pm 3{ }^{\circ} \mathrm{C}$ sıcaklıkta ve $\% 65 \pm 5$ bağıl nem şartlarında 2 ay bekletilmiştir.

\section{Metot}

Fiziksel özelliklerin belirlenmesinde $2 \times 2 \times 3$ $\mathrm{cm}$ ölçülerinde test örnekleri kullanılmıştır. Fiziksel özelliklerin belirlenmesi için 50 adet test örneği hazırlanmıştır. Örnekler üzerinde, rutubet miktarı (r) TS 2471'e göre, hava kurusu yoğunluk $\left(D_{12}\right)$ ve tam kuru yoğunluk (Do) TS 2472'ye göre, radyal, teğet, boyuna genişleme TS 4084'e ve hacmen genişleme TS 4086'ya göre belirlenmiştir. Lif doygunluk noktası (LDN) ise formül (2)'ye göre belirlenmiştir. Hacimsel genişleme oranlarının hesaplanmasında aşağıdaki formül kullanılmıştır.

$$
\alpha(\%)=\frac{\text { Doygun ölçü }(\mathrm{mm})-\text { Tam kuru ölçü }(\mathrm{mm})}{\text { Tam kuru ölçü }(\mathrm{mm})} \times 100
$$

Burada,

$\alpha=$ Hacimsel genişleme oranı (\%)'dir.

Hacimsel genişleme oranı $\left(\alpha_{v}\right)$, teğet, radyal ve boyuna yöndeki genişleme oranlarının $\left(\alpha_{t}, \alpha_{r}, \alpha_{l}\right)$ toplamından elde edilmiştir. Diğer taraftan LDN, formül (2)'ye göre hesaplanmıştır.

Burada,

$$
\operatorname{LDN}(\%)=\frac{\alpha_{\mathrm{v}}}{\mathrm{D}_{0}} \times 100
$$

$\alpha_{v}$ : Hacmen genişleme oranı (\%)

$D_{0}$ : Tam kuru yoğunluk $\left(\mathrm{gcm}^{-3}\right)^{\prime}$ tur.

Mekanik özelliklerden, eğilme direnci TS

2474 'e, eğilmede elastikiyet modülü TS 2478 'e, şok direnci TS 2477'ye ve vida tutma direnci ise TS EN 13446 'ya uygun olarak test edilmiştir. Eğilme direnci test örnekleri $2 \times 2 \times 36 \mathrm{~cm}$ ölçülerinde, şok direnci test örnekleri $2 \times 2 \times 30 \mathrm{~cm}$ ölçülerinde ve vida tutma direnci test örnekleri $5 \times 5 \times 5 \mathrm{~cm}$ ölçülerinde $15^{\prime} \mathrm{er}$ adet ve öz odunu, diri odun içerikleri eşit olacak şekilde hazırlanmıştır. 
Vida tutma direnci test örneklerine ön delik açılmamıştır. Denemelerde $4 \times 50 \mathrm{~mm}$ çinko vida kullanılmıştır. Vidanın oduna girme derinliği $20 \mathrm{~mm}$ olarak ayarlanmıştır. Test hızı $4 \mathrm{mmdk}^{-1}$ olarak yapılmıştır. Eğilme direncinde mesnetler arası mesafe $30 \mathrm{~cm}$ ve şok direncinde $24 \mathrm{~cm}$ olarak ayarlanmıştır. Eğilme direnci ve şok direnci testinde kuvvet radyal yüzeye (teğet yönde) uygulanmıştır.

\section{Bulgular ve Tartışma}

Yapılan testler sonunda elde edilen bazı fiziksel ve mekanik özelliklere ait sonuçlar, Sedir ağacıyla bazı ağaç türlerinin fiziksel özelliklerinin, vida tutma kapasitelerinin, eğilme direnci değerlerinin, elastikiyet modülü değerinin ve dinamik eğilme (şok) direnci kıyaslamaları sırasıyla Çizelge 1'de, Çizelge 2'de, Çizelge 3'te, Çizelge 4'te, Çizelge $5^{\prime}$ te ve Çizelge $6^{\prime}$ da verilmiştir. Çizelge 1 incelendiğinde, tam kuru yoğunluk değerinin 497 $\mathrm{kgm}^{-3}$, teğet yönde genişleme yüzdesinin \%6.4, radyal yönde genişleme yüzdesinin $\% 4$, boyuna yönde genişleme yüzdesinin $\% 0.2$, hacmen genişleme yüzdesinin \%10.6, genişleme anizotropisinin 1.66, lif doygunluk noktasının \%21.3 ve iki hafta sonunda aldığı su miktarının \%80.7 olduğu görülmektedir. Elde edilen bu verilere göre, sedir odununu Bozkurt ve Göker (1996) tarafından yapılan sınıflandırmaya göre lif doygunluk noktası çok düşük olan ağaç türleri grubunda yer almaktadır. Ayrıca Çetin ve Gündüz (2016) tarafından yapılan derleme çalışmada verilen bilgilerle kıyaslandığında, Türkiye'de doğal olarak yetişen ağaç türlerine göre, Sahil çamı hariç ve ayrıca Çavuş (2020) tarafından ardıç odununun hacmen genişleme yüzdesi hariç, Toros sediri odununun hacmen genişleme yüzdesi daha oldukça düşüktür. Odunun daralma ve genişleme yüzdesini etkileyen önemli bazı faktörler vardır. Bunlar; ağaç türü, odun türü, odun yoğunluğu ve hücre çeperinde S2 tabakasında fibril açıları şeklinde sıralanabilir. Ağaç türünün odunun daralma ve genişleme yüzdesi üzerine etkisinin olduğu ve düşük yoğunluğa sahip bazı türler hariç, geniş yapraklı ağaç odunlarının iğne yapraklı ağaç odunlarına göre daha yüksek daralma ve genişleme yüzdelerine sahip oldukları bilinmektedir (Bozkurt Göker, 1996; Bozkurt ve Erdin, 1997; Örs ve Keskin, 2001).

Genç odun-olgun odun ve öz odun-diri odun gibi farklı özelliklere sahip olan odun kısımlarının (odun türü) daralma-genişleme gibi fiziksel özellikleri de birbirlerinden farklılık göstermektedir (Bozkurt ve Erdin, 1997; Bal 2011; Bal ve ark., 2012). Odunun daralma ve genişleme yüzdelerini etkileyen bir diğer faktör odun yoğunluğudur. Odunun yoğunluğu arttıkça genel olarak daralma-genişleme yüzdeleri artar. Yapılan önceki çalışmalarda bu ilişki belirlenmiştir
(Malkoçoğlu, 1994; Bozkurt Göker, 1996; Bal 2011; Bal ve Bektaş, 2018). Yapılan bu çalışmada Toros sediri odunun tam kuru yoğunluğu $497 \mathrm{kgm}^{-3}$ olarak belirlenmiştir. Aslında, bu yoğunluk değerine sahip olan odun örneklerinin daralma-genişleme yüzdelerinin biraz daha yüksek olması beklenir. Genelde bu yoğunluğa sahip olan çam türlerinin hacmen genişleme yüzdeleri \%10'dan daha yüksektir. Ancak yukarıda verilen bilgilerde yoğunluğun etkili olan tek faktör olmadığı ifade edilmişti. Bu bilgilerin yanında, odunun daralma ve genişleme yüzdesini etkileyen bir diğer faktör de odunun içerdiği ekstraktif maddelerdir. Bu konuda yapılan bir çalışmada, ekstraktif maddeler odunun yoğunluğunun artmasına neden olurken, daralma ve genişleme yüzdelerinin artmasına neden olmamaktadır. Bu nedenle regresyon denklemine göre pozitif-artan bir ilişki belirlenememektedir (Bal ve ark., 2011). Odun yoğunluğu ile hacmen genişleme oranı arasında pozitif bir ilişki varken su alma oranı arasında negatif bir ilişki vardır ve yoğunluk arttıkça su alma oranı (uzun süreli bekletmeler sonunda elde edilen) azalmaktadır. Benzer sonuçlar, Bal ve Bektaş (2012) tarafından da okaliptüs odununda tespit edilmiştir. Ayrıca, Bal ve ark., (2011) tarafından yapılan çalışmada, sedir odunun, kesimden hemen sonra ölçülen taze haldeki rutubet yüzdesi ile tam kuru yoğunluk arasındaki ilişki belirlenmiş ve negatif bir ilişki olduğu hem genç odun ve hem de olgun odun kısımlarından alınan test örneklerinde belirlenmiştir.

Çizelgeye 1'e göre, teğet, radyal ve enine yüzeylerde yapılan vida tutma testi sonuçları sırasıyla, $31.4 \mathrm{Nmm}^{-2}, 29.7 \mathrm{Nmm}^{-2}$ ve $28.5 \mathrm{Nmm}^{-2}$ olarak tespit edilmiştir. En yüksek vida tutma direnci teğet yüzeyde ve en düşük ise enine yüzeyde elde edilmiştir. Vida tutma direnci üzerine yapılan önceki çalışmalarda da benzer sonuçlar tespit edilmiştir (Çizelge 2). Odun hücrelerinin çoğunluğunun boyuna yönde uzanmasının genel bir sonucu olarak enine yüzeyde ölçülen vida tutma direnci diğer yüzeylerde ölçülenlerden daha düşük olmaktadır. Bu farklılık diğer bazı mekanik test sonuçlarında da görülmektedir. Örneğin önceki çalışmalarda, statik sertlik testi sonuçlarının özellikle iğne yapraklı ağaçlarda, enine yüzeyde diğer yüzeylere göre daha yüksek olduğu tespit edilmiştir (Güleç, 2011; Bal ve ark., 2012; Ayata ve ark., 2018; Ayata, 2020; Çavuş, 2020). Eğilme direnci ve eğilmede elastikiyet modülü testi sonuçları Çizelge $1^{\prime}$ de, Bazı ağaç türlerinde belirlenmiş olan eğilme direnci değerleri Çizelge 3'de ve Bazı ağaç türlerinde belirlenmiş olan elastikiyet modülü değerleri Çizelge 4 'de verilmiştir. Çizelge 1 incelendiğinde, eğilme direnci ve elastikiyet modülü sırasıyla, $94.3 \mathrm{Nmm}^{-2}$ ve 8069 $\mathrm{Nmm}^{-2}$ olarak tespit edilmiştir. Çizelge $1^{\prime}$ de verilen 
hava kurusu yoğunluk değeri olan $517 \mathrm{kgm}^{-3}$ olan bir odun türünün eğilme direnci ve elastikiyet modülü değerleri yaklaşık olarak beklenen düzeyde ölçülmüştür.

Dinamik eğilme (şok) direnci testi sonuçları Çizelge 1'de ve test sonrası örnekler Şekil 1'de verilmiştir. Testler sonunda elde edilen verilere göre şok direnci $0.210 \mathrm{kgmcm}^{-2}$ olarak ölçülmüştür. Bu değer, Bal ve ark., (2012) tarafından Toros sediri genç ve olgun odununda belirlenen şok direnci değerlerinden küçüktür. Bu farklılıkların odun yoğunluğu, yetişme yeri ve test örneklerinin alındığı yer gibi faktörlerden kaynaklanabileceği söylenebilir. Örneklerin kırılma bölgeleri incelendiğinde genelde kıymıksı olduğu görülmektedir. Sadece birkaç örnekte kısa kıymıklar oluşmuştur. Şok direnci testi sonrası test örneklerinin kırılma noktalarında meydana gelen kıymıklı veya kıymıksız kırılma şekilleri, test edilen masif ağaç malzemenin tokluk özelliğini göstermektedir. İlgili standarda göre kırılma noktasında $3 \mathrm{~mm}$ 'den daha uzun kıymık oluşması, malzemenin sünek özellik gösterdiğini; kıymık boyu
$3 \mathrm{~mm}$ 'den daha kısa olan kırılma şekilleri ise gevrek malzemeyi işaret etmektedir. Illgili standarda göre, bu çalışmada denemeleri yapılan sedir odunu gevrek özellik göstermektedir denebilir.

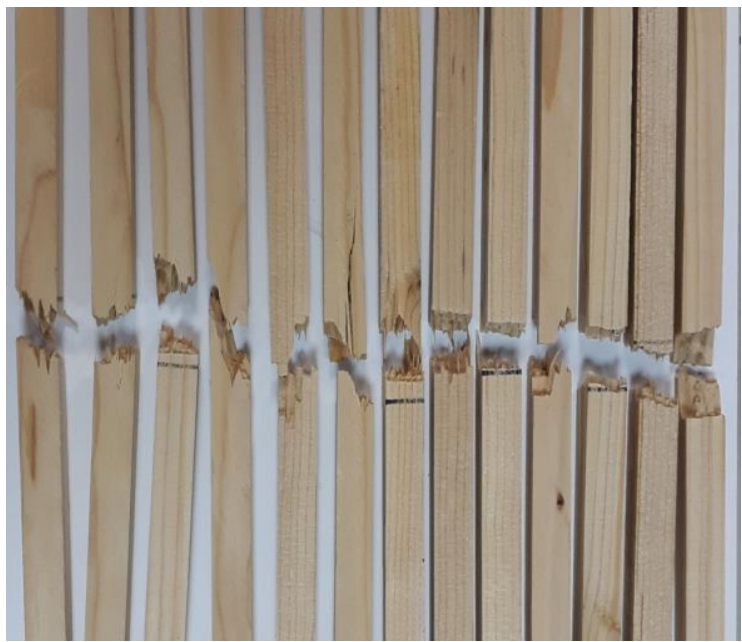

Şekil 1. Dinamik eğilme (şok) direnci testi sonrası örnekler.

Çizelge 1. Sedir odununun bazı fiziksel ve mekanik özellikleri.

\begin{tabular}{|c|c|c|c|c|c|}
\hline & Test & $\begin{array}{l}\frac{\pi}{E} \\
\frac{\pi}{\pi} \\
\stackrel{T}{ \pm}\end{array}$ & 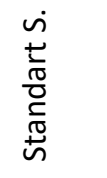 & $\begin{array}{l}\frac{\varepsilon}{J} \\
\frac{\varepsilon}{\sqrt{v}} \\
\frac{\sqrt[v]{0}}{\Sigma}\end{array}$ & 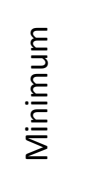 \\
\hline \multirow{9}{*}{$\begin{array}{l}\bar{\Xi} \\
\overline{\tilde{N}} \\
i \frac{1}{4}\end{array}$} & Tam Kuru Yoğunluk (Do) $\left(\mathrm{kgm}^{-3}\right)$ & 497 & 52 & 584 & 426 \\
\hline & Teğet Genişleme (\%) & 6.4 & 1.1 & 10.9 & 4.4 \\
\hline & Radyal Genişleme (\%) & 4.0 & 0.9 & 5.7 & 2.2 \\
\hline & Boyuna Genişleme (\%) & 0.2 & 0.1 & 0.4 & 0.0 \\
\hline & Hacmen Genişleme (\%) & 10.6 & 1.7 & 14.1 & 7.0 \\
\hline & Genişleme Anizotropisi & 1.66 & 0.35 & 3.43 & 1.23 \\
\hline & Lif Doygunluk Noktası (\%) & 21.3 & 2.7 & 31.2 & 15.3 \\
\hline & İki hafta sonunda aldığı su miktarı (\%) & 80.7 & 10.9 & 99.4 & 52.5 \\
\hline & Hava Kurusu Yoğunluk $\left(\mathrm{kgm}^{-3}\right)$ & 517 & 17 & 493 & 550 \\
\hline \multirow{6}{*}{ 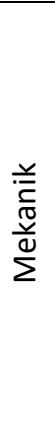 } & Teğet Yüzeyde Vida Tutma Direnci $\left(\mathrm{Nmm}^{-2}\right)$ & 31.4 & 2.2 & 27.0 & 34.9 \\
\hline & Radyal Yüzeyde Vida Tutma Direnci $\left(\mathrm{Nmm}^{-2}\right)$ & 29.7 & 2.6 & 26.0 & 34.0 \\
\hline & Enine Yüzeyde Vida Tutma Direnci $\left(\mathrm{Nmm}^{-2}\right)$ & 28.5 & 3.4 & 20.7 & 34.0 \\
\hline & Eğilme Direnci $\left(\mathrm{Nmm}^{-2}\right)$ & 94.3 & 18.1 & 63.6 & 131.2 \\
\hline & Elastikiyet Modülü $\left(\mathrm{Nmm}^{-2}\right)$ & 8069 & 1358 & 6469 & 10491 \\
\hline & Dinamik Eğilme (Şok Direnci $\left(\mathrm{kgmcm}^{-2}\right)$ & 0.210 & 0.051 & 0.145 & 0.361 \\
\hline
\end{tabular}


Çizelge 2'de görüldüğü gibi, sedir odununun hacmen genişleme oranı orman ürünleri sektöründe yaygın şekilde kullanılan karaçam ve kızılçama yakın sonuçlar vermiştir.

Çizelge 2. Sedir ağacıyla bazı ağaç türlerinin fiziksel özelliklerinin kıyaslanması.

\begin{tabular}{|c|c|c|c|c|c|c|c|}
\hline $\begin{array}{l}\text { Ağaç } \\
\text { Türü }\end{array}$ & 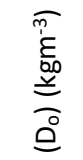 & $\frac{\bar{d}}{\frac{0}{0}}$ & $\frac{\widehat{\alpha}}{\frac{0}{0}}$ & $\frac{\widehat{a}}{\frac{0}{0}}$ & $\frac{\bar{a}}{\frac{d}{d}}$ & $\frac{\widehat{a}}{\frac{0}{0}}$ & Kaynak \\
\hline Sedir (Cedrus Libani A. Rich) & 497 & 6.40 & 4.00 & 0.20 & 10.60 & 1.66 & Tespit \\
\hline Göknar (Abies bornmülleriana Mattf.) & 400 & 8.45 & 4.17 & 1.002 & - & 2.02 & Korkut ve Bektaş, (2008) \\
\hline Duglas Göknarı (Pseudotsuga menziesii) & 390 & 8.00 & 4.3 & - & 12.3 & 1.86 & Ay, (1994) \\
\hline Karaçam (Pinus nigra Arnold) & 540 & 7.60 & 3.7 & 0.3 & 11.3 & 2.05 & Gündüz, (1999) \\
\hline Sarıçam (Pinus sylvestris L.) & 500 & 4.40 & 2.5 & 0.9 & - & 1.76 & Özan ve ark., (2017) \\
\hline Kızılçam (Pinus brutia Ten.) & 510 & 7.70 & 4.8 & - & 12.6 & 1.60 & Bektaş, (1997) \\
\hline \multirow[t]{2}{*}{ Doğu Ladini (Picea Orientalis L. ) } & 410 & 8.64 & 5.41 & - & - & 1.59 & Aydın ve Çolak, (2003); \\
\hline & & & & & & & Bozkurt ve Erdin, (2011) \\
\hline
\end{tabular}

$D_{0}$ : Tam Kuru Yoğunluk, $\alpha_{t}$ : Teğet Yönde Genişleme, $\alpha_{r}$ : Radyal Yönde Genişleme, $\alpha_{1}$ : Boyuna Yönde Genişleme, $\alpha_{v}$ : Hacmen Genişleme, $\alpha_{t} / \alpha_{r}$ : Genişleme Anizotropisi Oranı.

Çizelge 3'te sedir ağacıyla bazı ağaç türlerinin vida tutma kapasitelerinin kıyaslanması yapıımıştır.
Buna göre çizelgedeki iğne yapraklı ağaç odunları içinde en yüksek vida tutma kapasitesi sedirde gerçekleşmiştir.

Çizelge 3. Sedir ağacıyla bazı ağaç türlerinin vida tutma kapasitelerinin kıyaslanması.

\begin{tabular}{|c|c|c|c|c|}
\hline \multirow[b]{2}{*}{ Ağaç Türü } & \multicolumn{3}{|c|}{ Vida Tutma Direnci } & \multirow[b]{2}{*}{ Kaynak } \\
\hline & $\begin{array}{l}\text { Teğet } \\
\text { Yüzey }\end{array}$ & $\begin{array}{l}\text { Radyal } \\
\text { Yüzey }\end{array}$ & $\begin{array}{l}\text { Enine } \\
\text { Yüzey }\end{array}$ & \\
\hline Sedir (Cedrus Libani A. Rich) & $31.40 \mathrm{Nmm}^{-2}$ & $29.70 \mathrm{Nmm}^{-2}$ & $28.50 \mathrm{Nmm}^{-2}$ & Tespit \\
\hline Sedir (Cedrus Libani A. Rich) & 239 kgf & - & - & Ferah, (1991) \\
\hline Göknar (Abies bornmülleriana Mattf.) & $168 \mathrm{kgf}$ & - & - & Ferah, (1991) \\
\hline Karaçam (Pinus nigra Arnold.) & $238 \mathrm{kgf}$ & - & - & Ferah, (1991) \\
\hline Sarıçam (Pinus sylvestris L.) & $201 \mathrm{kgf}$ & - & - & Ferah, (1991) \\
\hline Sarıçam (Pinus sylvestris L.) & $15.69 \mathrm{Nmm}^{-2}$ & - & $12.70 \mathrm{Nmm}^{-2}$ & Perçin ve Ayan (2012) \\
\hline Kızılçam (Pinus brutia Ten.) & $219 \mathrm{kgf}$ & - & - & Ferah, (1991) \\
\hline
\end{tabular}

Çizelge 4. Sedir ağacıyla bazı ağaç türlerinin eğilme direnci değerlerinin kıyaslanması.

\begin{tabular}{lll}
\hline Ağaç Türü & $\mathrm{Nmm}^{-2}$ & Kaynak \\
\hline Sedir (Cedrus Libani A. Rich) & 94.30 & Tespit \\
Sedir (Cedrus Libani A. Rich) & 75.31 & Berkel, (1954) ve Demetçi, (1986) \\
Göknar (Abies bornmülleriana Mattf.) & 73.00 & As ve ark., (2001) \\
Karaçam (Pinus nigra Arnold) & 90.68 & Kardaş, (2014) \\
Sarıçam (Pinus sylvestris L.) & 100.00 & As ve ark., (2001) \\
Kızılçam (Pinus brutia Ten.) & 82.00 & As ve ark., (2001) \\
Doğu Ladini (Picea Orientalis L.) & 51.96 & As ve ark., (2001) \\
\hline
\end{tabular}

Çizelge 4'e göre sarıçamdan sonraki en yüksek eğilme direnci sedirde ölçülmüştür. Bu değer özellikle üzerine yük binen konstrüksiyonlar açısından çok önemlidir.

Çizelge 5'te sedirin eğilmede elastikiyet modülü değeri yaygın kullanılan iğne yapraklı ağaç odunlarının elastikiyet modülü değerlerine yakın olup; (Doğu ladini hariç) orman ürünleri alanında diğer türlere alternatif olarak kullanılabileceği konusunda fikir vermektedir. 
Çizelge 5. Sedir ağacıyla bazı ağaç türlerinin elastikiyet modülü değerinin kıyaslanması.

\begin{tabular}{lll}
\hline Ağaç Türü & $\mathrm{Nmm}^{-2}$ & Kaynak \\
\hline Sedir (Cedrus Libani A. Rich) & 8069.00 & Tespit \\
Göknar (Abies bornmülleriana Mattf.) & 7870.50 & Özçiftçi ve Batan, (2009) \\
Karaçam (Pinus nigra Arnold) & 7742.03 & Karademir, (2012) \\
Sarıçam (Pinus sylvestris L.) & 8215.00 & Atılgan ve ark., (2017) \\
Sarıçam (Pinus sylvestris L.) & 8355.72 & Özçiftçi ve Batan, (2009) \\
Kııılçam (Pinus brutia Ten.) & 7061.7 & As ve ark., (2001) \\
Doğu Ladini (Picea Orientalis L.) & 10528.00 & As ve ark., (2001) \\
\hline
\end{tabular}

Çizelge 6, özellikle darbe ve çarpmalar karşısında gösterilen mukavemet açısından önemli bir gösterge olan dinamik eğilme (Şok) direnci verilerini içermektedir. Buna göre, sedir odununun ölçülen değeri çizelgedeki diğer tüm iğne yapraklı ağaç odunlarınkinden düşüktür. Buradan anlaşılan şu ki, ani çarpma ve darbelere maruz kalma ihtimali olan ahşap ürünlerin (Çeşitli alet sapları, spor aletleri, oyuncak vb. gibi) yapımında sedir odunu kullanılırken bu özelliği dikkate alınmalı; daha dirençli alternatif türler göz ardı edilmemelidir.

Çizelge 6. Sedir ağacıyla bazı ağaç türlerinin dinamik eğilme (şok) direnci kıyaslanması.

\begin{tabular}{lll}
\hline Ağaç Türü & Şok Direnci & Kaynak \\
\hline Sedir (Cedrus Libani A. Rich) & $0.21 \mathrm{kgmcm}^{-2}$ & Tespit \\
Göknar (Abies bornmülleriana Mattf.) & $0.25 \mathrm{kgmcm}^{-2}$ & Özçiftçi ve Batan, (2009) \\
Sarıçam (Pinus sy/vestris L.) & $0.37 \mathrm{kgmcm}^{-2}$ & Özçiftçi ve Batan, (2009) \\
Karaçam (Pinus nigra Arnold) & $0.56 \mathrm{Nmm}^{-2}$ & As ve ark., (2001) \\
Kızılçam (Pinus brutia Ten.) & $0.26 \mathrm{Nmm}^{-2}$ & As ve ark., (2001) \\
Doğu Ladini (Picea Orientalis L. ) & $0.30 \mathrm{Nmm}^{-2}$ & As ve ark., (2001) \\
\hline
\end{tabular}

Şekil 2'de eğilme direnci testi esnasında elde edilen yük-deformasyon grafiği verilmiştir. Grafik incelendiğinde elastik bölgenin bazı istisnalar hariç 4-5 mm aralığında, deformasyon aralığının ise 8 örnek için 4-6 mm, 8 örnek için 6-7 mm, 7 örnek için de 7-8 mm olduğu görülmektedir. Tüm test örneklerinin en fazla 7-8 mm'lik bir deformasyon sonunda tamamen kırıldığı ve testin sonlandığı görülmektedir. Grafikte test sonu kademeli azalan şekilde değildir. Bu şekilde ani kırılma ile sonuçlanan test örneklerinin, tokluk özelliği bakımından sınıflandırıldığında, gevrek (kırılgan) malzeme özelliği gösterdiği söylenebilir.

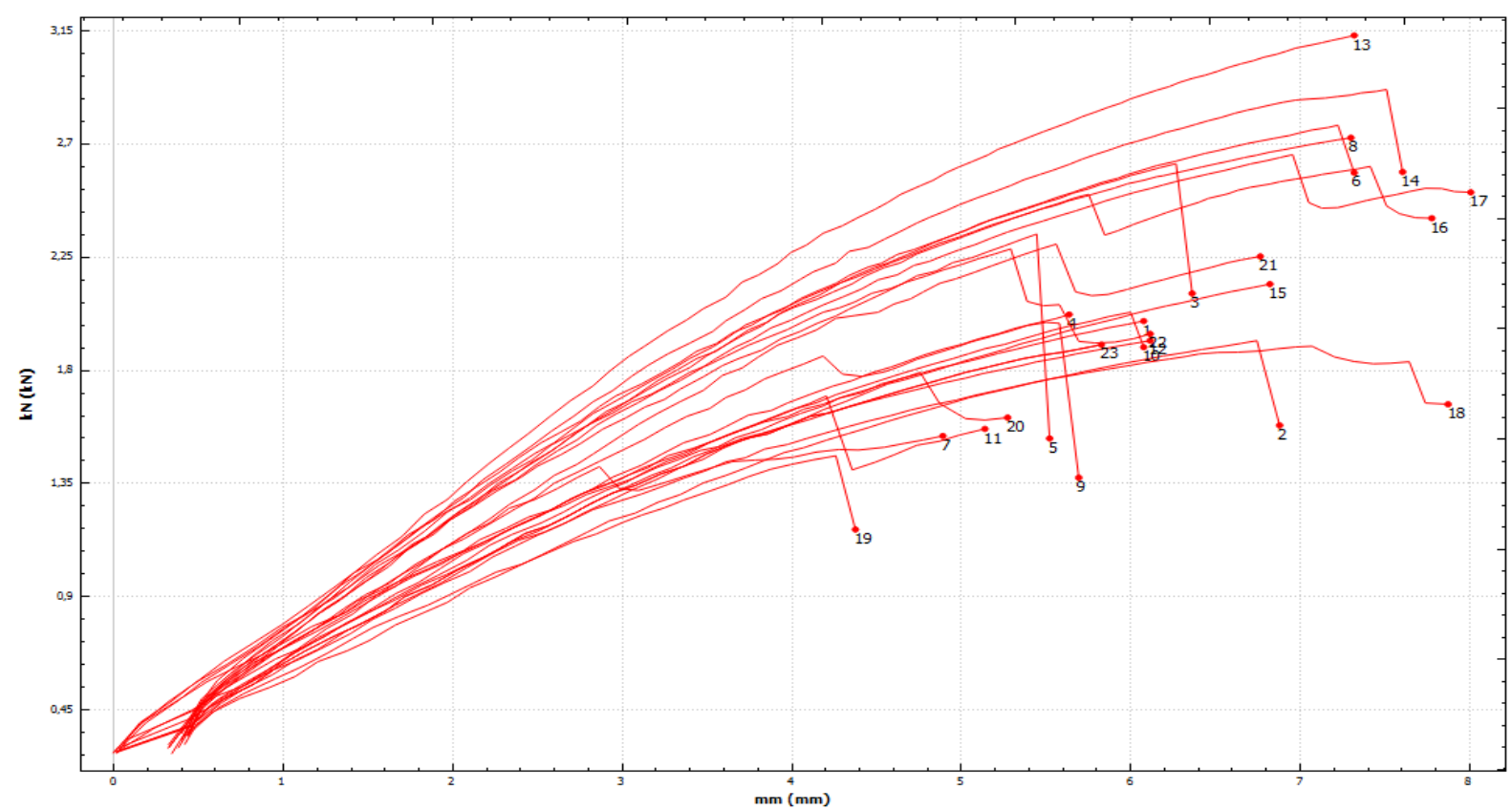

Şekil 2. Eğilme direnci testinde yük-deformasyon grafiği. 
Bir ağaç malzemenin vida tutma kapasitesi, o malzemeden yapılan ürünün kullanım ömrü süresince performansını etkileyen önemli noktalardan birisidir. Şekil 3, Şekil 4 ve Şekil 5'te vida tutma kapasitesi testi esnasında elde edilen yükdeformasyon grafikleri verilmiştir. Grafikler incelendiğinde enine yüzeyde bazı istisnalar hariç, maksimum direnç değerlerinin $2.4 \mathrm{~mm}$ ile $3.5 \mathrm{~mm}$ deformasyon aralığında; radyal yüzeyde, $2.4 \mathrm{~mm}$ ile $3 \mathrm{~mm}$ arasında ve teğet yüzeyde $3 \mathrm{~mm}$ ile $3.6 \mathrm{~mm}$ arasında olduğu görülmektedir. Bunun nedeni vida uygulama doğrultusunun enine ve radyal yüzeyde liflere paralel, teğet yüzeyde ise liflere dik olmasıdır. Dolayısıyla, vida dişlerinin liflere daha sıkı tutunması söz konusudur. Bir çalışmada karaçam (Pinus nigra Arnold) odununun radyal, teğet ve enine yüzeydeki vida tutma kapasiteleri sırasıyla $16.26 \mathrm{Nmm}^{-2}, 16.78$ $\mathrm{Nmm}^{-2}$ ve $14.92 \mathrm{Nmm}^{-2}$ olarak; Uludağ göknarının odununun (Abies bornmuelleriana Mattf.) ise radyal, teğet ve enine yüzeydeki vida tutma kapasiteleri sırasıyla $16.34 \mathrm{Nmm}^{-2}, 17.37 \mathrm{Nmm}^{-2}$ ve $15.08 \mathrm{Nmm}^{-2}$ olarak tespit edilmiştir (Perçin ve ark., 2017). Görüldüğü gibi, sedir odununun vida tutma kapasitesi orman ürünleri sektöründe yoğun olarak kullanılan karaçam ve göknardan oldukça yüksektir. Ferah (1991)'ın, vida tutma kabiliyeti bakımından yaptığı sıralama yüksekten düşüğe doğru meşe, kayın, sedir, karaçam, kızılçam, sarıçam ve göknar olarak rapor etmiştir. Çalışmamızdaki vida tutma kapasitesine ilişkin bulgular sedir için önceki çalışmalarda bulunan değerler ile uyumludur.

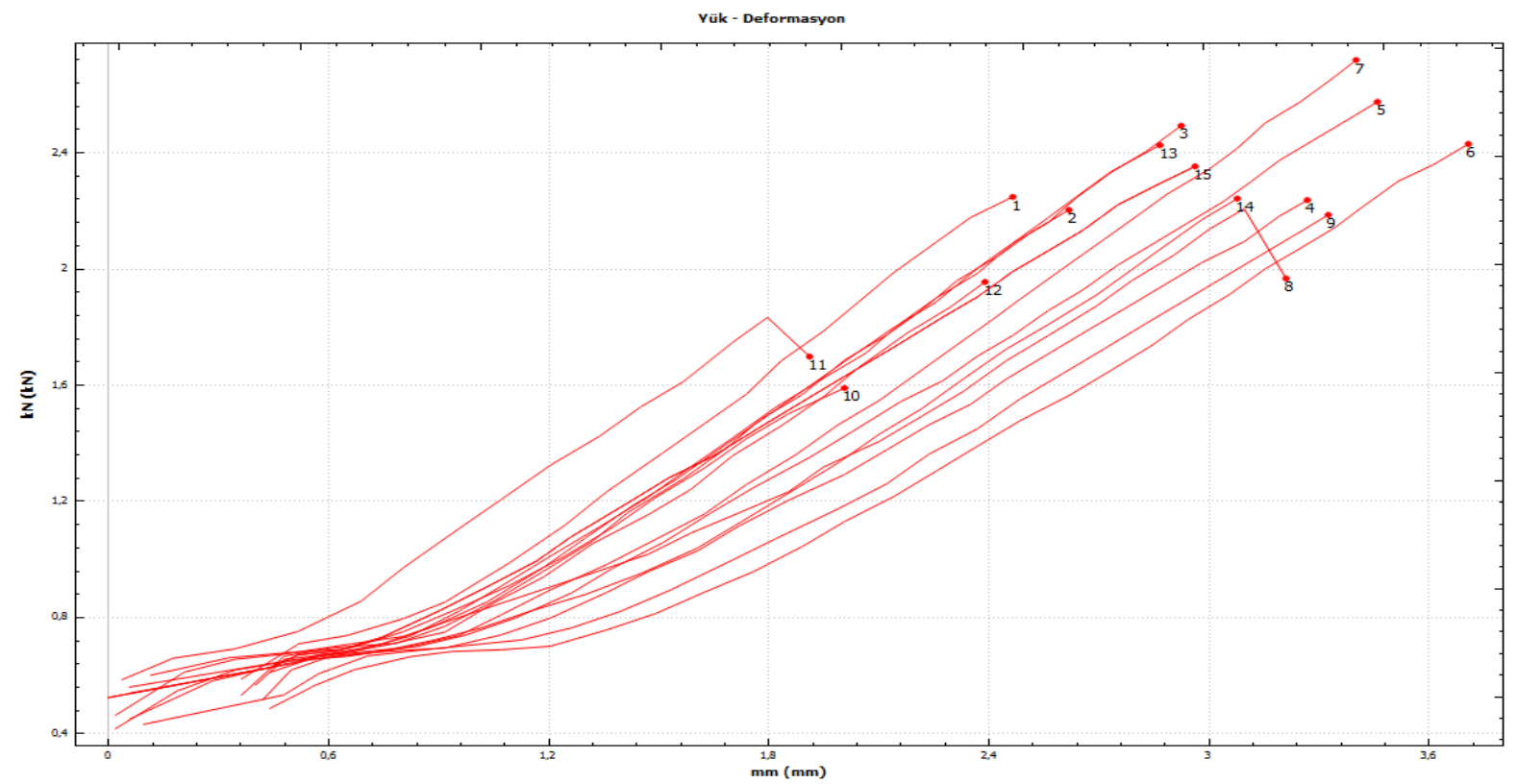

Şekil 3. Enine yüzeyde vida tutma direnci.

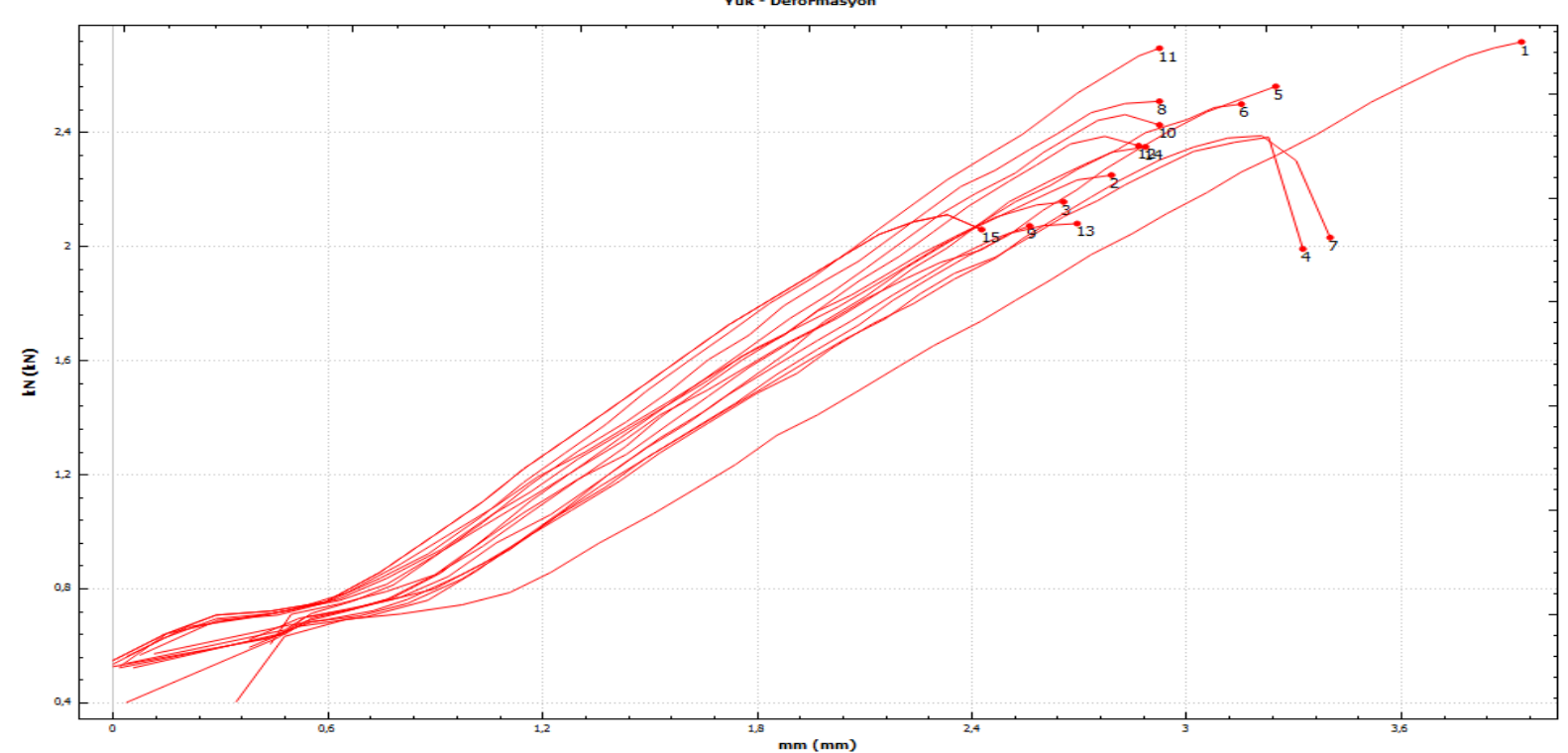

Şekil 4. Radyal yüzeyde vida tutma direnci. 


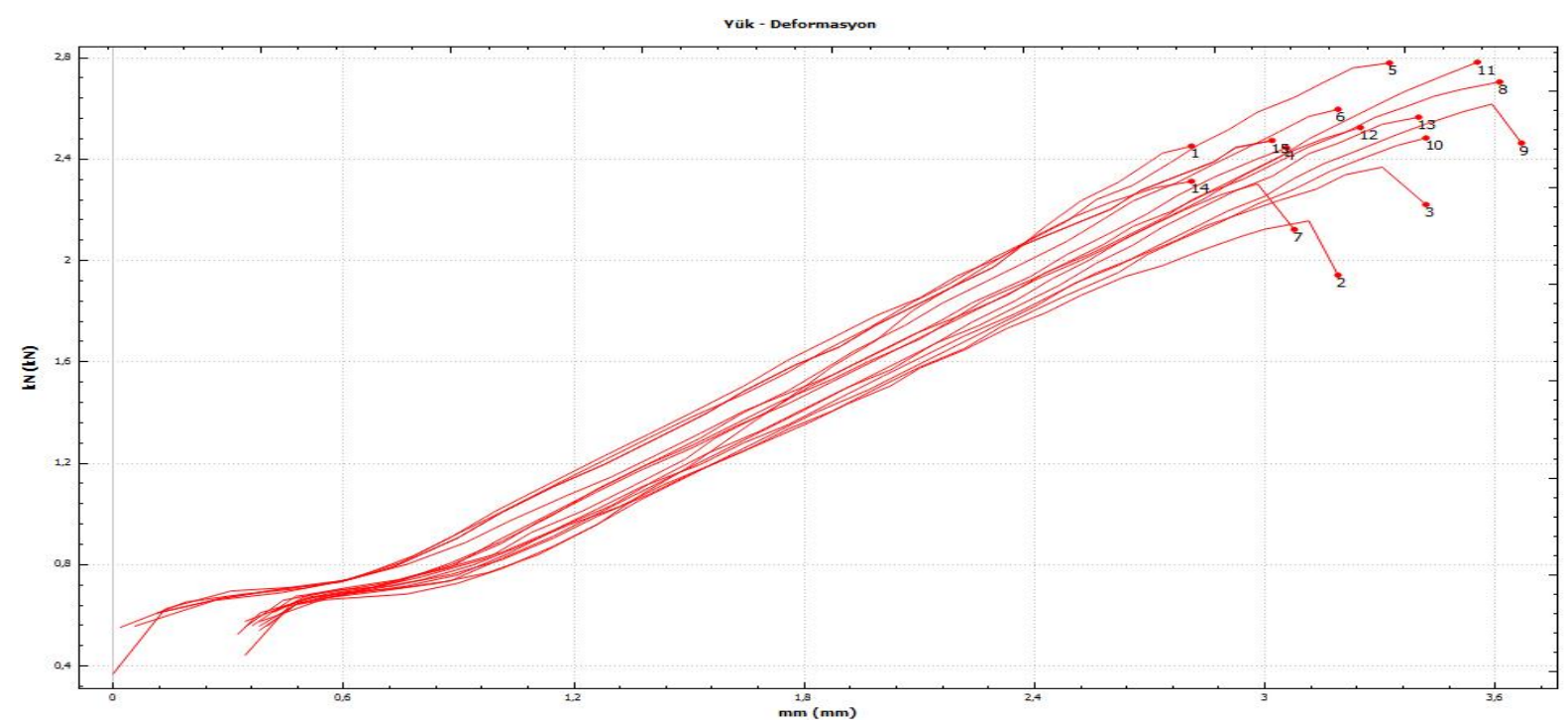

Şekil 5. Teğet yüzeyde vida tutma direnci.

\section{Sonuç ve Öneriler}

Bu çalışmada, Toros sediri odununun bazı önemli fiziksel ve mekanik özellikleri araştırılmıştır. Elde edilen verilere göre şu sonuçlar söylenebilir;

- Toros sediri odunu, tam kuru yoğunluğu bakımından diğer iğne yapraklı ağaç türlerine yakın ve orta yoğunluk değerine sahiptir.

- Toros sediri odunu tam kuru yoğunluk değerine göre hacmen daralma yüzdesi düşük olan bir ağaç türüdür.

- Önemli fiziksel özelliklerden olan lif doygunluk noktası \%21.3 olarak hesaplanmış ve bu değer ile lif doygunluk noktası çok düşük olan ağaç türleri grubunda yer almaktadır.

- Vida tutma direnci değeri, en düşük enine yüzeyde yapılan testlerde ve en yüksek teğet yüzeyde yapılan testlerde elde edilmiştir.

- Eğilme direnci ve elastikiyet modülü testi sonuçları, yoğunluk değerine göre normaldir ancak, şok direnci değerinin yoğunluk değerine göre düşük olduğu belirlenmiştir.

Bulgular, sedir ağacının orman ürünleri sektöründe özellikle statik yük binen ve/veya çarpmaya maruz kalan ahşap yapı elemanlarının üretiminde malzeme seçiminde yol gösterici olacaktır.

Teşekkür: Bu çalışmada değerli katkı ve desteklerinden dolayı Sayın Prof. Dr. Bekir Cihad BAL ve Sayın Dr. Öğr. Üyesi Vedat ÇAVUŞ’a sonsuz teşekkür ederim.

Çıkar Çatışması Beyanı: Makale yazarları aralarında herhangi bir çıkar çatışması olmadığını beyan ederler.
Araştırmacıların Katkı Oranı Beyan Özeti: Yazarlar makaleye eşit oranda katkı sağlamış olduklarını beyan ederler.

\section{Kaynaklar}

As, N., Koç, H., Doğu, D., Atik, C., Aksu, B., Erdinler, S., 2001. Türkiye'de Yetişen Endüstriyel Öneme Sahip Ağaçların Anatomik, Fiziksel, Mekanik ve Kimyasal Özellikleri, İstanbul Üniversitesi Orman Fakültesi Dergisi, Yayın No: 51 (1): 71-88.

Atılgan, A., Ulusoy, H., Peker, H., 2017. Bazı odun türlerinde bitki ekstrakt boyasının eğilme direnci/elastiklik modülüne etkisi. Biyoloji Bilimleri Araştırma Dergisi, 10(1): 10-13.

Ay, N., 1994. Duglas Odununun (Pseudotsuga menziesii (Mirb.) Franco) Anatomik, Fiziksel ve Mekanik Özellikleri, Doktora Tezi, Orman Endüstri Mühendisliği A.B.D., Fen Bilimleri Enstitüsü, Karadeniz Teknik Üniversitesi.

Ayata, Ü., 2020. Ayous odununun bazı teknolojik özelliklerinin belirlenmesi ve ısıl işlemden sonra renk ve parlaklık özellikleri, Mobilya ve Ahşap Malzeme Araştırmaları Dergisi, 3(1): 22-33. DOI: 10.33725/mamad. 724596.

Ayata, Ü., Çavuş, V., Bal, B., C., Efe, F., T., 2018. Dut, Doğu Çınarı, Kızılçam ve Sedir Ağaç Türlerinde Janka Sertlik Değerinin Belirlenmesi. $2^{\text {nd }}$ International Symposium on Innovative Approaches in Scientific Studies, November 30- December 2, 2018, Samsun, Turkey, SETSCl Conference Indexing System, Volume 3, 1490-1494.

Aydın, İ., Çolak, S., 2003. Buharlama işlemi yapılmış ladin (picea orientalis I.) Odununun bazı Fiziksel ve mekanik özelliklerindeki 
değişmeler. Kafkas Üniversitesi Artvin Orman Fakültesi Dergisi (2003) : 1-2 (6367).

Bal, B. C., 2011. Okaliptüs grandis (Eucalyptus grandis W. Hill ex maiden) odununun fiziksel ve mekanik özellikleri ve lamine ağaç malzeme üretiminde kullanılması üzerine araştırmalar. KSÜ, Fen Bilimleri Enstitüsü, Doktora tezi.

Bal, B., C., Bektaş, I, 2012. The physical properties of heartwood and sapwood of Eucalyptus grandis. Pro Ligno, 8(4): 35-43.

Bal, B., C., Bektaş, İ., 2018. Kayın ve kavak odunlarında bazı fiziksel özelliklerle yoğunluk ilişkisinin belirlenmesi. Mobilya ve Ahşap Malzeme Araştırmaları Dergisi, 1(1): 1-10.

Bal, B., C., Bektaş, I.., Kaymakçı, A., 2012. Toros Sedirinde Genç Odun ve Olgun Odunun Bazı Fiziksel ve Mekanik Özellikleri. KSÜ Mühendsilik Bilimleri Dergisi, 15(2): 17-27.

Bektaş, i.., 1997. Kızılçam (Pinus brutia Ten.) Odununun Teknolojik Özellikleri ve Yörelere Göre Değişimi, Doktora Tezi, Orman Endüstri Mühendisliği A.B.D., Fen Bilimleri Enstitüsü, İstanbul Üniversitesi.

Berkel, A., 1954. Lübnan sedirinin teknik vasıfları. Tarım Bakanlığı Orm. Gen. Müd. Yayın No: 93, 86 s. Ankara.

Bozkurt, Y., Erdin, N., 1997. Ağaç Teknolojisi Ders Kitabı. i..Ü. Orman Fakültesi, Yayın no: 445, S:136 ve 336, İstanbul.

Bozkurt, Y., Erdin, N., 2011. Ağaç Teknolojisi Ders Kitabı. i.Ü. Orman Fakültesi, İstanbul Üniversitesi Yayın No: 5029, Orman Fakültesi Yayın No: 445, ISBN No: 978-975404-900-8, İstanbul.

Bozkurt, Y., Göker, Y., 1996. Fiziksel ve Mekanik Ağaç Teknolojisi. i.ü., Orman Fakültesi Yayınları, Üniversite Yayın No: 3944, İstanbul.

Çavuş, V., 2020. Kokulu ardıç odununun bazı fiziksel ve mekanik özellikleri üzerine bir araştırma. Mobilya ve Ahşap Malzeme Araştırmaları Dergisi, 3(1): 1-9. DOI: 10.33725/mamad.717060.

Çetin, F., Gündüz, G., 2016. Türkiye'deki Bazı Ağaç Türü Odunlarının Fiziksel Özellikleri Üzerine Yapılan Araştırmaların Değerlendirilmesi. Bartın Orman Fakültesi Dergisi, 2016, 18 (2): 175-193.

Demetçi, Y., E., 1986. Toros sediri odununun bazı fiziksel ve mekaniksel özellikleri üzerine araştırmalar. Orm. Araş. Enst. Teknik Bülten No: 180, 59 s. Ankara.

Doğu, D., Koç, H., As, N., Atik, C., Aksu, B., Erdinler, S., 2001. Türkiye'de yetişen endüstriyel öneme sahip ağaçların temel kimlik bilgileri ve kullanıma yönelik genel değerlendirme. iÜ, Orman Fakültesi Dergisi, Seri B, Cilt: 51, Sayı: 2.

Ferah, O., 1991. Bazı önemli ağaç türlerimizin vida ve çivi tutma direnç özelliklerinin belirlenmesi. Ormancılık Araştırma Enstitüsü Yayınları, Teknik Bülten, No:252, Ankara.

Göker, Y., 1992. Türkiye Akdeniz Bölgesi Ormanları ve Ormancılığına İlişkin Yaklaşımlar: Akdeniz Bölgesi Doğal Ağaç Türlerinin Teknolojik ve Endüstriyel Özellikleri. iü Orman Fakültesi Ormancılık Araştırma ve Uygulama Merkezi Müdürlüğü Yayınları, Müdürlük Yayın No 1, 169-180, İstanbul. 1992.

Güleç, T., 2011. Kahramanmaraş bölgesinde büyük göknar kabuk böceği (Pityokteines curvidens)'den zarar görmüş Toros göknar odununun bazı fiziksel, kimyasal ve mekanik özelliklerinin belirlenmesi. Kahramanmaraş Sütçü İmam Üniversitesi, Fen Bilimleri Enstitüsü, Yüksek Lisans Tezi, Kahramanmaraş.

Gündüz, G., 1999. Camiyanı Karaçamı (Pinus nigra Arn. subsp. pallasiana var. Pallasiana)'nın Bazı Anatomik, Teknolojik ve Kimyasal Özellikleri, Orman Endüstri Mühendisliği A.B.D., Doktora Tezi, Fen Bilimleri Enstitüsü, Zonguldak Karaelmas Üniversitesi.

Karademir, E., 2012. Jeotermal akışkanlarla emprenye edilen ahşabın performansı: Uşak yöresi örneği, Süleyman Demirel Üniversitesi, Fen Bilimleri Enstitüsü, Orman Endüstri Mühendisliği Anabilim Dalı, Yüksek Lisans Tezi, Isparta, $72 \mathrm{~s}$.

Kardaş, İ., 2014. Kütahya-Simav yöresi jeotermal kaynaklarının emprenye maddeleri açısından incelenmesi ve bu kaynakların ahşabın bazı özellikleri üzerine etkilerinin araştırılması, Süleyman Demirel Üniversitesi, Fen Bilimleri Enstitüsü, Orman Endüstri Mühendisliği Anabilim Dalı, Yüksek Lisans Tezi, Isparta, $83 \mathrm{~s}$.

Korkut, S., Bektaş i., 2008. The effects of heat treatment onphysical properties of Uludag fir (Abies bornmuelleriana Mattf.) and Scots pine (Pinus sylvestris L.) wood, Forest Products Journal Vol. 58, no.3.

Malkoçoğlu, A., 1994. Doğu Kayını (Fagus orientalis L.) Odununun Teknolojik Özellikleri. Karadeniz Teknik Üniversitesi, Fen Bilimleri Enstitüsü, Doktora Tezi, Trabzon.

Öktem, E., Sözen, R., 1992. Sedir odununun anatomik ve teknolojik özellikleri ile 
kullanım yerleri. Ormancılık Araştırma Enstitüsü Yayınları, Muhtelif Yayınlar Serisi: 66, El Kitabı Dizisi: 6, Sedir, sayfa: 287-297, Ankara.

Örs, Y., Keskin, H., 2001. Ağaç Malzeme Bilgisi, Gazi Üniversitesi Ders Kitabı. S:77, Ankara.

Özan, Z., E., Onat, S., M., Aydemir D., 2017. Sarıçam ve Uludağ Göknar Odunlarının Bazı Özellikleri Üzerine Termal Muamelenin Etkileri, Bartın Orman Fakültesi Dergisi, 19(1): 187-193, DOI: 10.24011/barofd.313318.

Özçiftçi, A., Batan, F., 2009. Bor yağının ağaç malzemenin bazı mekanik özelliklerine etkisi, Politeknik Dergisi, 12(4): 287-292.

Perçin, O., Ayan, S., 2012. Isıl İşlem Uygulanmış Ağaç Malzemede Vida Çekme Direncinin Belirlenmesi, İleri Teknoloji Bilimleri Dergisi, Cilt 1, No 1, 57-68, 2012.

Perçin, O., Yaşar, Ş., Ş., Altunok, M., Uzun, O., 2017. Determination of Screw Withdrawal Resistance of Some Heat-Treated Wood Species, Drvna Industrija 68 (1) 61-68 (2017).

Sofuoğlu, D., Kurtoğlu A., 2015. Effects of Machining Conditions on Surface Roughness in Planing and Sanding of Solid Wood. Drvna industrija: Scientific journal of wood technology, Vol. 66 No. 4, 2015.

TS 2471, 1976. Odunda Fiziksel ve Mekaniksel Deneyler İçin Rutubet Miktarı Tayini. Türk Standartları Enstitüsü, Ankara, 1976.

TS 2472, 1976. Odunda Fiziksel ve Mekaniksel Deneyler İçin Birim Hacim Ağırlığı Tayini. Türk Standartları Enstitüsü, Ankara, 1976.

TS 2474, 1976. Odunun Statik Eğilme Dayanımının Tayini. Türk Standartları Enstitüsü, Ankara, 1976.

TS 2477, 1976. Odunun Çarpmada Eğilme Dayanımının Tayini. Türk Standartları Enstitüsü, Ankara, 1976.

TS 2478, 1976. Odunun Statik Eğilmede Elastiklik Modülünün Tayini. Türk Standartları Enstitüsü, Ankara, 1976.

TS 4084, 1983. Odunda Radyal ve Teğet Doğrultuda Şişmenin Tayini. Türk Standartları Enstitüsü, Ankara, 1983.

TS 4086, 1983. Odunda Hacimsel Şişmenin Tayini. Türk Standartları Enstitüsü, Ankara, 1983.

TS EN 13446, 2005. Ahşap Esaslı Levhalar Bağlayıcıların Geri Çıkma Kapasitesinin Tayini. 2005 Türk Standartları Enstitüsü, Ankara. 